\title{
HYBRID WARFARE - A FORM OF ASYMMETRIC CONFLICT
}

\author{
Laura-Maria HERȚA \\ “Babeș-Bolyai” University, Cluj-Napoca, Romania \\ laura.herta@euro.ubbcluj.ro
}

\begin{abstract}
For a few decades now, a vivid scholarly discussion centred on new forms of conflict has been developing. Military historians and political scientists entered into debates building consistent pro and counter-arguments about whether armed conflict at the end of the $20^{\text {th }}$ century and beginning of the $21^{\text {st }}$ century features novel aspects. Several concepts have been coined in order to describe the nature and dynamic of warfare in a post-clausewitzian/post-conventional era, such as new wars, Fourth Generation Warfare, compound wars and last, but not least, hybrid warfare. This article will briefly present the core of each category and will stress hybrid warfare as most recent development of such intellectual categories. The main argument defended here is that hybrid wars are a contemporary feature of global politics, mostly associated with non-state actors (such as terrorist groups) and with Russia's strategies in eastern Ukraine, but also that they are a form of asymmetric conflict.
\end{abstract}

Keywords: new wars, compound warfare, fourth generation warfare, hybrid warfare, Russian hybrid warfare

\section{Introduction}

The transformation of war and the new forms of belligerence emerging at the end of the $20^{\text {th }}$ century became salient issues within consistent debates among military experts, political scientists, and military historians. Several concepts have been coined in order to describe the nature and dynamic of warfare in a postclausewitzian/post-conventional era or to best illustrate types of conflict in the $21^{\text {st }}$ century. On the other hand, other approaches followed suit in order to prove that the transformative processes in warmaking capacities do not indicate new forms per se or new categories at the end of the $20^{\text {th }}$ century, but rather a development pertaining to previous historical recurrences. In other words, the latter approach insists upon the combination of regular and irregular tactics as a historical reality of war.

In what follows, the article will present the core arguments of specific concepts (such as new wars, fourth generation warfare, compound warfare) which have been theorized in order to reveal the transformative nature of warfare.

\subsection{New wars}

Much of the discussion on the transformation of war relied on distinguishing between conventional interstate warfare and unconventional intrastate armed conflicts. The late 1990s and beginning of the $21^{\text {st }}$ century witnessed the old wars-new wars dichotomy and the consequences of globalization as catalysts for a new pattern of belligerence.

The term "new wars" prompted a large and interesting debate in the academic milieu and is the centrepiece of most scholarly works tackling the transformation of war. On the one hand, several scholars, such as Mary Kaldor [1], Herfried Münkler [2], Mark Duffield [3], Dietrich Jung and Klaus 
Schlichte [4], Bjørn Møller [5], focused on the main differences between conventional, Clausewitzean, trinitarian warfare (associated with the rise of the modern state) and the novel aspects of post-Cold War armed conflicts. The general observation of scholars concerned with the new wars is that after the Second World War, the classical, Clausewitzean pattern of inter-state war was gradually replaced by various dynamics of intra-state violence. Despite obvious regional peculiarities, recent and contemporary armed conflicts share certain structural features: the asymmetrical configuration of the belligerents, lack of respect for the jus in bello, and violence directed against civilians. The "new wars" approach contends that globalization produced transnational and sub-state threats in a manner that changes dramatically the nature of warfare. As such, the de-statization of war [6], the transformative power of economic globalization [7], identity politics [8], the forced displacement and victimization of civilians determine the profound changes in recent and contemporary belligerence. Herfried Münkler argued that "the classical model of inter-state war [...] seems to have been discontinued", states tend to lose their de facto monopoly on organized violence and are replaced by "military entrepreneurs". According to Münkler, "states have given up their de facto monopoly on war, and what appears ever more frequently in their stead are para-state or even partly private actors - from local warlords and guerrilla groups through firms of mercenaries operating on a world scale to international terror networks" [9]. The main argument pertaining to the features of new wars is related to a "multiplicity of interest groups", which breed on war economies and hence have no direct or lucrative interests in initiating peace processes or in the "renunciation of violence". The author's contention about the transformative nature of war is centred on several developments: $\mathrm{d}$-statization of war or privatization of military force; greater asymmetry of military force; autonomization of forms of violence [10]. Since such wars tend to be prolonged (because of shadow economies, support from outside powers, increased consumption of resources, and local warlords' reliance on profits from war economy), one major observation is that the "short-wars between states" (from the midseventeenth to the early twentieth century) were replaced by "long wars within societies." The latter imply the following intertwining characteristics: the asymmetry of forces/belligerents; the gradual privatization of violence; the deviation from codified rules of warfare; and the use of force (in its utmost brutal force) against civilians [11].

Similarly, Mary Kaldor and Basker Vashee argued that new wars display new phenomena associated with armed conflict, such as "large-scale population displacement, social disruption, and widespread destruction of historic and cultural monuments" [12], all indicating the suffering of civilians and brutality targeting non-combatants. The authors stress the fact that the nature of war has changed, since "overall casualties and direct participation in wars tend to be lower, but the ration of civilian to military casualties appears to have risen quite dramatically." [13]

On the other hand, a series of scholarly works argued against the "newness" of contemporary wars. Siniša Malešević [14], Mats Berdal [15], E.A. Henderson and D. Singer were adamant to demonstrate that characterizing features of contemporary wars (like massacres, banditry, population displacement, or sexual violence as tactics of war) are in fact not new, but have a long history; hence, "many of the 'new wars' are simply amalgamations of various interstate, extrastate, and intrastate wars - i.e., the 'old wars' - that have been lumped into a single category" [16].

Theses of new wars were revisited and certain scholars, such as Mary Kaldor, addressed the issue in response to criticism 
and re-articulated main arguments by showing that " "new wars' should be understood not as an empirical category but rather as a way of elucidating the logic of contemporary war that can offer both a research strategy and a guide to policy." [17]. According to Newman, "the new wars literature, while exaggerating the peculiarities of contemporary conflict, has done a great service in deepening understanding of civil war" and "literature on the social and economic dynamics of civil war offers rich insights for the security discourse, including human security" [18].

\subsection{Fourth Generation Warfare}

Alongside the old wars versus new wars debate, another interesting concept emerged, namely Fourth Generation Warfare $(4 \mathrm{GW})$. Certain core elements are present in the two approaches mentioned so far: the "blurring nature" of contemporary conflict, i.e. the blurring of war and peace, public and private or combatants and noncombatants, but also "the weakening of the state and the rise of non-state actors willing and able to challenge the legitimacy of the state" [19]. Already in 1989, "the changing face of war" was linked to fourth generation warfare by an article in the Marine Corps Gazette: "fourth generation warfare seems likely to be widely dispersed and largely undefined; the distinction between war and peace will be blurred to the vanishing point. It will be nonlinear, possibly to the point of having no definable battlefields or fronts. Also, the distinction between 'civilian' and 'military' may disappear." [20] Proponents of Fourth Generation Warfare also insist on this aspect: " $4 \mathrm{GW}$ is conducted simultaneously in population centers, rural areas, and virtual networks. It moves constantly to avoid detection and to target its enemy's vulnerabilities." [21] The concept of Fourth Generation Warfare centers on the ability of (militarily) weaker belligerents to combine conventional and unconventional means in order to pose a serious threat to the opponent's political will. As shown by Thomas Hammes, "it is rooted in the fundamental precept that superior political will, when properly employed, can defeat greater economic and military power." [22] Consequently, Fourth Generation Warfare "does not attempt to win by defeating the enemy's military forces. Instead, combining guerrilla tactics or civil disobedience with the soft networks of social, cultural and economic ties, disinformation campaigns and innovative political activity, it directly attacks the enemy's political will." [23]

Criticism against Fourth Generation Warfare came from historians and the concept has been rebuffed as "elegant irrelevance". [24] The critique focuses on the history of irregular warfare which reveals a mixture of conventional and unconventional means. Such mixture is then not so new, since it has been evidenced by much earlier writings, such as Callwell's treatise Small Wars [25] already published in 1906, according to this view. [26]. Reactions to the concept of $4 \mathrm{GW}$ indicate that, in fact, "what has occurred is simply part of war's evolution, a shift in degree rather than kind" [27]. Consequently, much of the criticism contends that fourth generation war "falsely claims that traditional state-to-state warfare is a relic of the past." [28]

\subsection{Compound Warfare}

The concept compound warfare has been employed by Thomas M. Huber in reference to major wars that had "significant regular and irregular components fighting simultaneously under unified direction" [29]. Huber focused on illustrative case studies, such as the American Revolution, compound warfare in the Vietnam war, the Soviets' experience in Afghanistan etc. According to Huber, "Compound warfare is the simultaneoususe of a regular or main force and an irregular or guerrilla force against an enemy. In other words, the $\mathrm{CW}$ operator increases his military leverage by applying both conventional and 
unconventional force at the same time." [30]. However, Hoffman argued that the theory of compound warfare "offers synergy and combinations at the strategic level", but, in fact, the historical cases presented by Huber indicate that "when militia and irregular forces were ever employed with regular forces, $[\ldots]$ the irregular forces $[\ldots]$ were second-rate conventional forces." [31].

\section{Hybrid warfare}

\subsection{Origin and development of the concept}

The term hybrid warfare emerged during the first decade of the $21^{\text {st }}$ century when several scholars were focusing on "the blending and blurring character of future conflicts" [32]. It has been used over the last ten years in reference to non-state actors waging (sometimes seemingly successful) wars against militarily superior state adversaries, but also as illustrative term for Russia's strategies in eastern Ukraine. The term was used for the first time in 2002 in a master's thesis by William J. Nemeth [33]. In his Future war and Chechnya: a case for hybrid warfare, Nemeth used this concept in order to analyze how "increasing dislocation brought about by globalization enhances the drive toward ethnic or tribal affinity", hence determining "devolving societies" to reorganize their military forces and conduct in warfare. Additionally, Nemeth claimed that "hybrid warfare will become increasingly prevalent" and that the "Chechen insurgency [is] a model for hybrid warfare." [34]

It was in 2007 that Franck Hofmann tackled hybrid threats as those that are simultaneous, fused and subordinated to one command unit. Focusing on "multimodal activities" which are "operationally and tactically directed and coordinated within the main battlespace to achieve synergistic effects", Hoffman argued that "hybrid wars incorporate a range of different modes of warfare including conventional capabilities, irregular tactics and formations, terrorist acts including indiscriminate violence and coercion, and criminal disorder" [35]. The underpinning postulate is that "hybrid wars blend the lethality of state conflict with the fanatical and protracted fervour of irregular warfare" [36].

Hoffman uses the "multi-modal" underlying nature in hybrid warfare in order to distinguish it from previous guerrilla tactics or from compound warfare whose aim was to pose a persistent threat by protracting the conflict. In such a scenario, the militarily, technologically and numerically weaker side aimed at avoiding direct confrontations with the opponent and decisive battles were not strategically envisioned. "Hybrid opponents", Hoffman argues, "seek victory by the fusion of irregular tactics and the most lethal means available in order to attack and attain their political objectives" and "the disruptive component of Hybrid Wars does not come from high-end or revolutionary technology, but from criminality" [37]. The traditional intellectual or conceptual categories seem obsolete, since they are based on separation between regular and irregular warfare, which becomes transcended by "a fusion of war forms". According to Hoffman, "instead of separate challengers with fundamentally different approaches (conventional, irregular or terrorist), we can expect to face competitors who will employ all forms of war and tactics, perhaps simultaneously. Criminal activity may also be considered part of this problem as well, as it either further destabilizes local government or abets the insurgent or irregular warrior by providing resources, or by undermining the host state and its legitimacy" [38].

Hybrid wars, therefore, neither supplant conventional warfare, nor do they confine future threats to mere sub-state or transstate irregular actors. They represent the blending of various forms of tactics and strategies, the simultaneous military and cyber attacks, the instantaneity of targeting 
and inflicting harm, all facilitated by globalization and developments in technology and information. At the same time, hybrid wars will retain basic and brutal forms of violence, trying to instil terror and human costs, while exploiting virtual dimensions of warfare. Hybrid wars basically combine cyber, kinetic, media, terrorist, and military (regular and irregular) command structures. They blend malware and hacking with conventional military decision-making. [39]

\subsection{Non-state actors and hybrid warfare}

The term hybrid war is associated with nonstate actors launching military campaigns against states. The war fought by Israel against Lebanon-based Hezbollah in 2006 was the one that triggered preoccupation for the capacity of a non-state actor, such as Hezbollah, to pose a serious threat to the conventional Israeli Defence Forces (IDF) not because it merely employed irregular strategies, but because its strength combined military force with "political, social, diplomatic, and informational components that provide[d] bedrock support for its military organization" [40].

Sascha-Dominik Bachmann and Håkan Gunneriusson tackle the role the internet and social media as "enhancer and force multiplier" in terrorist activities and emphasize the "readiness, availability and affordability of using new technologies for setting up effective" systems of "command and control" [41]. Referring to non-state terrorist actors, such as Boko Haram, AlShabaab, ISIS, Bachmann and Gunneriusson stressed the increasing capacity of non-state actors to replicate the command and control structures of conventional military and observed that recent "developments have changed the traditional view of asymmetric warfare, where an AK-47 and the insurgent's morale were traditionally the only and often most important factors in achieving victory". The two scholars argued that "hybrid threats as such are not new threats; what is new is the recognition that such multi-modal threats command a 'holistic' approach, which combines traditional and non-traditional responses by state and NSAs [non-state actors] as well" [42].

\subsection{Russian hybrid warfare}

Recent literature links hybrid warfare with Russia's actions in eastern Ukraine and the subsequent annexation of Crimea. Most articles focus on Russia's combined strategies and tactics, ranging from subversion, cyber-attacks, media manipulation, the presence of "little green men", staged military exercises, criminal disorder, agitation and fifth columns. Several authors describe the entire set of tools employed by Russia in eastern Ukraine [43]. Some scholars focus on cyber warfare or information warfare as major shifts in Russia's strategies [44] while others are rather preoccupied with the asymmetric nature of Russia's operations [45]. Other approaches focus on the difficulty of conceptually coining Russia's strategy as hybrid war, terming them "grayzone wars" [46] or a form of "compound 'indirect' approach" [47]. Bachmann and Gunneriusson focused on the somehow "undefined nature of the conflict" stressing the difficulties over defining Russia's actions in Crimea as "war or civil unrest, interstate aggression or intrastate conflict" [48].

Russia's recourse to information warfare and cyber attacks is considered crucial in transforming the modes of waging war against Ukraine. Keir Giles focused on the way in which information technologies and social media were employed as both tools for disinformation, amounting to "hacking of the news" according to some [49], and for the media construction of Russia's version of events [50]. What Keir Giles dubs the "next phase of Russian information warfare" basically centres on employment of "Pro-Russian trolls - online profiles controlled by humans - and bots, those controlled by automated processes" 
[51]. A complex and systematic process has been developed, which tends to supplant the conventional deployment of troops, with "Russia amassing abilities on social media, ready to be deployed when needed" [52]. This led other scholars to assess Russia's actions in terms of capacity "to hybridize not only its actual warfare, but also its informational warfare" [53]. Russia's strategies in eastern Ukraine and the annexation of Crimea are considered hybrid challenges for the $21^{\text {st }}$ century, since they heavily rely on what Peter Pomerantsev and Michael Weiss have called " "the weaponization of information, culture and money', vital parts of the Kremlin's concept of 'non-linear' war' [54].

\section{Hybrid warfare as response to asymmetric relations}

The main argument defended here is that hybrid wars are a contemporary feature of global politics, mostly associated with nonstate actors (such as terrorist groups) and with Russia's strategies in eastern Ukraine, but also that they are a form of asymmetric conflict. I argue that Russia's hybrid war in Ukraine entails much more than military aggression against Ukraine and it is in fact a response to the West, more specifically to the global asymmetric conflict with the United States and Europe, since one major goal for Putin's Russia is to be on equal footing with the other important actors in world politics. Consequently, Russia's hybrid strategies constitute a response to a perceived asymmetric conflict.

As emphasized by James Wither, "many Russian commentators and analysts claim that Russia has been under sustained and effective information attack by the US since the 1980s" and hence, "from a Russian perspective, the seizure of Crimea and operations in eastern Ukraine are strategic defensive campaigns to counter US hybrid warfare against its national interests and values" [55].

In both the case of Russia and the case of non-state actors hybrid strategies were meant to counter-act militarily and technologically stronger opponents, namely states and their military arsenals such as Israel (in the case of Hezbollah) and the West, especially the United States (in the case of Russia).

In conclusion, hybrid warfare is an aggregate of blended strategies (facilitated by globalization and revolution in communications and internet, also triggering the instantaneity of attacks) employed by some military actors, which perceive themselves in an asymmetric conflict with an opponent, in an attempt to keep up with the uneven conditions.

\section{References}

[1] Mary Kaldor, New and Old Wars, Stanford: Stanford University Press, 2001; Mary Kaldor; Basker Vashee, (eds. on behalf of UNU World Institute for Development Economic Research), Restructuring the Global Military Sector. Volume I: New Wars, London, Washington: Pinter, 2001.

[2] Herfried Münkler, The New Wars, Cambridge, Cambridge University Press, 2005.

[3] Mark Duffield, Global Governance and the New Wars. The Merging of Development and Security, London, New York: Zed Books, 2001.

[4] Dietrich Jung; Klaus Schlichte, "From Inter-State War to Warlordism: Changing Forms of Collective Violence in the International System", in Håkan Wiberg; Christian P. Scherrer (eds.), Ethnicity and Intra-State Conflict, Brookfield USA: Ashgate, 1999, pp. 35-51.

[5] Bjørn Møller, "The Faces of War", in Håkan Wiberg; Christian P. Scherrer (eds.), Ethnicity and Intra-State Conflict, Brookfield USA: Ashgate, 1999, pp. 15-34.

[6] Münkler, op. cit., 2005.

[7] Kaldor; Vashee, op. cit., 2001. 
[8] Kaldor, op. cit., 2001.

[9] Münkler, op. cit., p. 1.

[10] Ibidem, p. 3.

[11] Ibidem.

[12] Kaldor, Vashee, op. cit., p. xi.

[13] Ibidem, p. 8.

[14] Siniša Malešević, The Sociology of War and Violence, Cambridge: Cambridge University Press, 2010.

[15] Mats Berdal, "How 'new' are 'new wars'? Global economic change and the study of civil war”, Global Governance, vol. 9, no. 4, Oct.-Dec. 2003, pp. 477-502.

[16] Henderson, Errol A.; Singer, J. (2002), "'New wars' and rumours of 'new wars"”, International Interactions: Empirical and Theoretical Research in International Relations, Vol. 28, issue 2, 2002, 4 p. http://www.tandfonline.com/doi/abs/10.1080/03050620212098, accessed September 2014.

[17] Mary Kaldor, “In Defence of New Wars”, Stability, 2(1): 4, 2013, pp. 1-16.

[18] Newman, Edward (2004), "The 'New Wars' Debate: A Historical Perspective Is Needed", Security Dialogue, vol. 35, no. 2, June 2004, p. 186, http://citeseerx.ist.psu.edu/viewdoc/download?doi=10.1.1.469.4895\&rep=rep1\&type=pdf , accessed October 2013.

[19] Franck G. Hoffman, Conflict in the $21^{\text {st }}$ Century: the Rise of Hybrid Wars, Potomac Institute for Policy Studies, 2007, p. http://www.potomacinstitute.org/images/stories/publications/potomac_hybridwar_0108.p df, accessed October 2016.

[20] William S. Lind; Keith Nightengale; John F. Schmitt; Joseph W. Sutton; Gary I. Wilson, "The Changing Face of War: Into the Fourth Generation", Marine Corps Gazette, October, 1989, $\quad$ p. 23, https://www.mcamarines.org/files/The\%20Changing\%20Face\%20of\%20War\%20-

\%20Into\%20the\%20Fourth\%20Generation.pdf, accessed December 2016.

[21] Steven C. Williamson, From Fourth Generation Warfare to Hybrid War, Strategy Research Project, U.S. Army War College, 2009, p. 3, http://indianstrategicknowledgeonline.com/web/FROM\%20FOURTH\%20GENERATIO N\%20to\%20hybrid.pdf, accessed December 2016.

[22] Thomas X. Hammes, "War evolves into the fourth generation", Contemporary Security Policy, vol. 26, issue 2, August 2005, pp. 189-221, http://www.tandfonline.com/doi/full/10.1080/13523260500190500? src=recsys, accessed December 2016.

[23] Ibidem.

[24] Kenneth F. McKenzie, "Elegant Irrelevance: Fourth Generation Warfare", Parameters, Autumn 1993, pp. 51-60.

[25] C. E. Callwell, Small Wars. Their Principles and Practice, London: Harrison and Sons, 1906.

[26] Antulio J. Echevarria II (2005), "Deconstructing the Theory of Fourth-Generation War", Contemporary Security Policy, vol. 26, issue 2, August 2005, pp. 233-241, http://www.tandfonline.com/doi/abs/10.1080/13523260500211066?journalCode=fcsp20, accessed December 2016.

[27] Hoffman, Conflict in the $21^{\text {st }}$ Century: the Rise of Hybrid Wars, 2007, p. 19. 
[28] Bettina Renz; Hanna Smith, Russia and Hybrid Warfare - Going beyond the Label, Report 1/2016, Aleksanteri Institute, University of Helsinki, Finland, p. 5, http://www.helsinki.fi/aleksanteri/english/publications/presentations/papers/ap_1_2016.p df, accessed November 2016.

[29] Hoffman, Conflict in the $21^{\text {st }}$ Century: the Rise of Hybrid Wars, 2007, p. 20.

[30] Thomas M. Huber (ed.), Compound Warfare. The Fatal Knot, University Press of the Pacific, 2004, p. 1.

[31] Hoffman, Conflict in the $21^{\text {st }}$ Century: the Rise of Hybrid Wars, 2007, p. 21.

[32] Ibidem, p. 31.

[33] Mihai Marcel Neag, "A New Typology of War -The Hybrid War", Revista Academiei Forțelor Terestre, 2016, Vol. 21, Issue 1, p. 16, http://www.armyacademy.ro/reviste/rev1_2016/NEAG.pdf, accessed November 2016.

[34] William J. Nemeth, Future war and Chechnya: a case for hybrid warfare, Master Thesis, California: Naval Postgraduate School Monterey, 2002, http://calhoun.nps.edu/bitstream/handle/10945/5865/02Jun_Nemeth.pdf?sequence=1, accessed December 2016

[35] Hoffman, Conflict in the $21^{\text {st }}$ Century: the Rise of Hybrid Wars, 2007, p. 29.

[36] Ibidem, p. 28.

[37] Ibidem, p. 29.

[38] Ibidem, p. 7.

[39] Laura-Maria Herța, "Russia's Hybrid Warfare. Why Narratives and Ideational Factors Play a Role in International Politics", On-line Journal Modelling the New Europe, Issue no. 21, December 2016, pp. 55-56.

[40] Russell Glenn, "Thoughts on "Hybrid" Conflict", Small Wars Journal, March 2009, p. 3, http://smallwarsjournal.com/jrnl/art/thoughts-on-hybrid-conflict, accessed November 2016

[41] Sascha-Dominik Bachmann; Håkan Gunneriusson, "Hybrid Wars: The 21 $1^{\text {st }}$-Century's New Threats to Global Peace and Security", Scientia Militaria, South African Journal of Military Studies, 2015, Vol. 43, No. 1, 2015, p. 83, http://scientiamilitaria.journals.ac.za/pub/article/view/1110/1107, accessed November 2016

[42] Ibidem, p. 86.

[43] Alexander Lanoszka, "Russian hybrid warfare and extended deterrence in eastern Europe", International Affairs, 2016, 92: 1, pp. 175-195, http://www.alexlanoszka.com/LanoszkaIAHybrid.pdf, accessed November 2016; Peter Pomerantsev; Michael Weiss, The Menace of Unreality: How the Kremlin Weaponizes Information, Culture and Money, New York: The Institute of Modern Russia, 2014, http://www.interpretermag.com/wp-

content/uploads/2014/11/The_Menace_of_Unreality_Final.pdf, accessed December 2016

[44] Bachmann; Gunneriusson, op. cit., 2015; Keir Giles, "The Next Phase of Russian Information Warfare", in Bettina Renz; Hanna Smith, Russia and Hybrid Warfare Going beyond the Label, Report 1/2016, Aleksanteri Institute, University of Helsinki, Finland, 2016, pp. 40-46.

[45] Rod Thornton, "Turning strengths into vulnerabilities: the art of asymmetric warfare as applied by the Russian military in its hybrid warfare concept", in Bettina Renz; Hanna Smith, Russia and Hybrid Warfare - Going beyond the Label, Report 1/2016, Aleksanteri Institute, University of Helsinki, Finland, pp. 52-60.

[46] Antulio J. Echevarria II, "How Should We Think about 'Gray-Zone' Wars?", in Bettina Renz; Hanna Smith, Russia and Hybrid Warfare - Going beyond the Label, Report 1/2016, Aleksanteri Institute, University of Helsinki, Finland, pp. 33-39. 
[47] Sibylle Scheipers, "Winning Wars without Battles: Hybrid Warfare and Other 'Indirect' Approaches in the History of Strategic Thought", in Bettina Renz; Hanna Smith, Russia and Hybrid Warfare - Going beyond the Label, Report 1/2016, Aleksanteri Institute, University of Helsinki, Finland, pp. 47-51.

[48] Bachmann; Gunneriusson, op. cit., 2015, pp. 88-89.

[49] Tikhonova, Polina (2015), "Russia Hacking Your News", ValueWalk, 14 March 2015, http://www.valuewalk.com/2015/03/russia-hacking-your-news/

[50] Keir Giles, "The Next Phase of Russian Information Warfare", in Bettina Renz; Hanna Smith, Russia and Hybrid Warfare - Going beyond the Label, Report 1/2016, Aleksanteri Institute, University of Helsinki, Finland, p. 40.

[51] Ibidem.

[52] Ibidem, p. 43.

[53] Peter Pomerantsev; Michael Weiss, The Menace of Unreality: How the Kremlin Weaponizes Information, Culture and Money, New York: The Institute of Modern Russia, 2014, p. 5.

[54] Ibidem, p. 4.

[55] James K. Wither, "Making Sense of Hybrid Warfare", Connections: The Quarterly Journal, 15, no. 2, 2016: 73, p. 80. 